\title{
Conservation of Citrus Germplasm in Vitro
}

\author{
M.L. Marin and N. Duran-Vila ${ }^{1}$ \\ Instituto Valenciano de Investigaciones Agrarias, Apartado Oficial, 46113 Moncada, Valencia, \\ Spain
}

Additional index words. sweet orange, trifoliate orange; rough lemon, Mexican lime, Cleopatra mandarin, grapefruit,
Citrus sinensis, Poncirus trifoliata, Citrus aurantifolia, Citrus limon

Abstract. A study was conducted to evaluate the potential of in vitro techniques for genetic conservation of citrus. A tissue culture system was developed using explants of juvenile 'Pineapple' sweet orange. It consisted of: a) establishment of primary cultures from nodal stem segments followed by the recovery of plants in vitro; and b) successive cycles of secondary cultures consisting of the culture of nodal stem segments from in vitro-grown plants, rooting of shoots obtained from nodal stem segments, and recovery of whole plantlets. Two parameters, K and K', based on the multiplication factors of the different stages of primary and secondary cultures are proposed to monitor the system as a potential tool for genetic conservation of citrus. The system also can be successfully used for the conservation of juvenile tissues of two sweet orange varieties [ Citrus sinensis (L.) Osb.], trifoliate orange [Poncirus trifoliata (L.) Raf.], Mexican lime [C. aurantifolia (Christm.) Swing.], and 'Eureka' lemon [ C. limon (L.) Burro. f.]. Chemical names used: 6-benzylaminopurine (BA); $\alpha$ - naphtbaleneacetic acid (NAA).

Several in vitro methods have been considered as alternatives to field genebanks for the genetic conservation of vegetatively propagated crops (Withers, 1980). Conventional tissue culture techniques, including classical micropropagation and routine maintenance of callus and cell suspensions by periodical subculturing, can be used for conservation of plant tissues and are available for many species (Bajaj, 1986; Styer and Chin, 1983), provided that the cultures can be easily handled and the potential to recover true-to-type plants is retained (Styer and Chin, 1983; Withers, 1980). The conservation methods suggested for vegetatively propagated species involve the culture of shoot-tips and buds that are maintained by periodical subculture of proliferating shoots or nodal stem segments. These methods have been successfully developed for coffee [ Coffea arabica L.], strawberry [ Fragaria spp.], cassava [ Manihot esculenta Crantz.], potato [ Solanum sp.], and grapevine [ Vitis spp.] (Boxus, 1974; Galzy, 1985; Henshaw et al., 1980; Hensky et al., 1983; Kartha et al., 1981; Rota et al., 1979, 1982). In addition, the cryopreservation of plant tissues is also under study, but now is restricted to a few species. Few successes have been reported with woody perennials (Bajaj, 1979; Kartha, 1981; Marin and Duran-Vila, 1988; Sakai, 1986; Withers, 1985).

The genetic conservation of citrus involves the conservation of samples representative of the wild species as a whole and of cultivated material. The latter should cover a wide range of genetic variability, including primitive, old, and current cultivars (IBPGR, 1982). Commercial cultivars are commonly propagated by air layering or grafting on seedling rootstock and, therefore, the genetic conservation of commercial rootstock should also be considered. The conservation of citrus through seeds is limited by a decrease in viability when they are stored for extended periods (Honjo and Nakagawa, 1978; King et al., 1981). Therefore, in most instances, their preservation implies

Received for publication 6 Mar. 1989. We thank J. Juarez and J.M. Arregui for their availability and assistance, and L. Navarro for his suggestions and comments. on genetic conservation of citrus. The research was supported by INIA, IBPGR, and a fellowship to the senior author provided by INIA and the Consellería de Agricultural de la Generalitat Valenciana. The results presented in this work are part of the research requirements necessary for the candidacy of M.L.M. to the PhD degree in biology. The cost of publishing this paper was defrayed in part by the payment of page charges. Under postal regulations, this paper therefore must be hereby marked advertisement solely to indicate this fact.

${ }^{\mathrm{t}}$ To whom correspondence should be addressed. the conservation of whole plants as field collections, cryoconservation (Marin and Duran-Vila, 1988; Mumford and Grout, 1979) or the maintenance of tissue cultures.

General in vitro techniques have been described for several citrus species and cultivars (Barlass and Skene, 1982; Chaturvedi and Mitra, 1974; Duran-Vila et al., 1989; Tisserat et al., 1979). In preliminary work, nucellar callus, shoot-tips, and buds were evaluated for genetic conservation in vitro. However, their maintenance for extended periods by periodical subculture was unsuccessful because callus did not retain morphogenic potential and the proliferating shoots and buds failed to grow after a few subcultures (Marin, 1988).

An alternative method for long-term maintenance of citrus tissue cultures is outlined in Fig. 1. Primary cultures consist of rooted shoots from nodal stem segments. Secondary cultures are initiated from nodal stem segments of rooted plants derived from the primary cultures. Successive cycles of secondary cultures would permit the long-term maintenance of explants and the periodic recovery of whole plants.

\section{Materials and Methods}

Source of tissue and preparation of explants. Unless otherwise stated, seedlings (1 to 2 years old) of 'Pineapple' sweet orange [Citrus sinensis (L.) Osb.] were used as a source of explants. In the assays to evaluate the application of the system to other Citrus species, seedlings (1 to 2 years old) of 'Mexican' lime, 'Eureka' lemon, 'Cleopatra' mandarin ( C. reshni Hort. ex Tan.), 'Madame Vinous' sweet orange, trifoliate orange, and 'Duncan' grapefruit ( $C$. paradisi Macf.) were used. An adult clone of 'Pineapple' sweet orange grafted on 'Troyer' citrange ( C. sinensis $\times P$. trifoliata) was used as a source of adult tissue. The source plants were grown in a greenhouse at 18 to $27 \mathrm{C}$.

Nodal explants were prepared as described by Duran-Vila et al. (1989). Stem pieces $(20 \mathrm{~cm})$ were stripped of leaves and thorns, disinfected by immersion for $10 \mathrm{~min}$ in a $2 \%(\mathrm{w} / \mathrm{v})$ sodium hypochlorite solution containing $0.1 \%$ Tween-20 and rinsed three times with sterile water. Explants were prepared by excising 2cm-long nodal stem segments containing an axillary bud.

Culture media. The basic nutrient solution (BNS) contained the inorganic salts of Murashige and Skoog (1962), 100 mesoinositol, 0.2 thiamine $\cdot \mathrm{HCl}, 1$ pyridoxine $\cdot \mathrm{HCl}, 1$ nicotinic acid, all in $\mathrm{mg} \cdot \mathrm{liter}^{-1}$, and $30 \mathrm{~g}$ sucrose/liter. Nodal segments were cultured on medium containing the BNS supplemented with BA. Rooting medium contained BNS supplemented with NAA and 

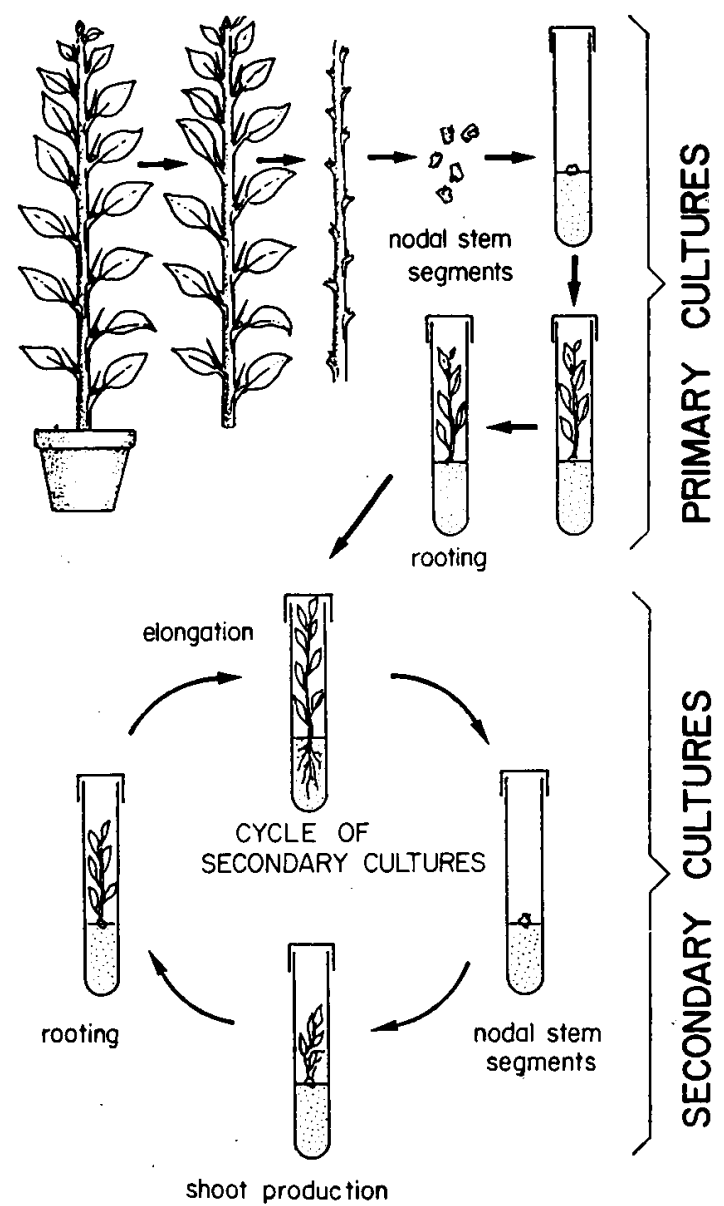

shoot production

Fig. 1. Maintenance of citrus by in vitro culture. Establishment of primary cultures (top); and cycle of secondary cultures (bottom).

elongation medium was identical to BNS. The $\mathrm{pH}$ of the media was adjusted to 5.7 with $1 \mathrm{~N} \mathrm{NaOH}$. The media were solidified by adding $10 \mathrm{~g}$ agar/liter (Difco Bacto agar), dispensed as 25$\mathrm{ml}$ aliquots into $150 \times 25 \mathrm{~mm}$ culture tubes, and sterilized by autoclaving for $15 \mathrm{~min}$ at $121 \mathrm{C}$.

Culture conditions. Cultures were maintained at $26 \pm 1 \mathrm{C}$, $60 \% \mathrm{RH}$, and with a $16-\mathrm{h}$ photoperiod $\left(40 \mathrm{~mol} \cdot \mathrm{s}^{-1} \cdot \mathrm{m}^{-2}\right)$ provided by daylight-type fluorescent lamps. Experiments were performed using at least 20 cultures per treatment.

Primary cultures. The culture of primary explants and production of in vitro plants of 'Pineapple' sweet orange were performed as described by Duran-Vila et al. (1989) (Fig. 1). Nodal stem segments from greenhouse-grown plants were bisected longitudinally and the portion containing the bud was cultured with the cut surface in contact with the medium containing BNS supplemented with $1 \mathrm{mg} \mathrm{BA} /$ liter. Unless otherwise stated, the number of axillary shoots that developed from each bud and that were at least $1 \mathrm{~cm}$ long was recorded 4 months later. Then a multiplication factor $\mathrm{k} 1(\mathrm{k} 1$ = number of shoots per number of cultured buds) was calculated (Fig. 2). The shoots were excised from the original explants, cultured for 21 days in rooting medium containing the BNS supplemented with $3 \mathrm{mg}$ NAA/ liter, and transferred to elongation medium. One month later, the number of rooted plantlets was recorded and a multiplication factor $\mathrm{k} 2(\mathrm{k} 2=$ number of rooted plantlets per number of cultured shoots) was calculated (Fig. 2).

Primary explants of 'Mexican' lime were cultured on medium containing $0.3 \mathrm{mg} \mathrm{BA} / \mathrm{liter}$. Assays to evaluate the optimal con-

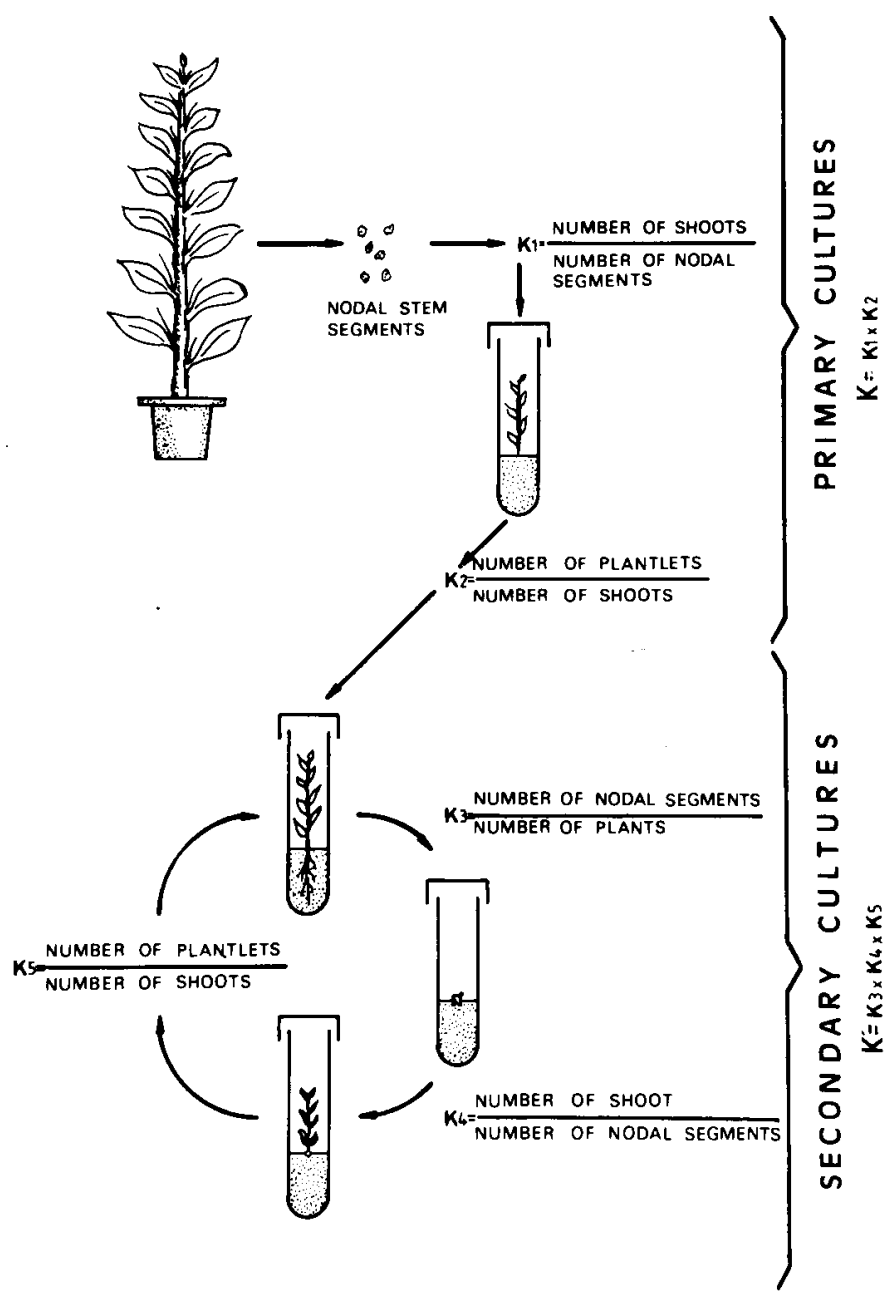

Fig. 2. Maintenance of citrus by in vitro cultures. Monitoring of primary cultures (top); and monitoring of secondary cultures (bottom).

centrations of BA and NAA for growth and development of nodal stem segments and recovery of rooted plants of 'Eureka' lemon, 'Cleopatra' mandarin, 'Madame Vinous' sweet orange, trifoliate orange, and 'Duncan' grapefruit were conducted following Duran-Vila et al. (1989).

Cycle of secondary cultures. Nodal stem segments were excised from in vitro-grown plantlets and transferred to fresh medium as described for primary cultures (Fig. 1). Unless otherwise stated, nodal stem segments ( 0.5 to $0.8 \mathrm{~cm}$ long) were obtained from 4-month-old in vitro-grown plants and the number of shoots, at least $1 \mathrm{~cm}$ long, that developed from each bud was recorded 4 months later. In vitro-grown plants were obtained from the secondary cultures by transferring these shoots to rooting and elongation media. Multiplication factors $\mathrm{k} 3(\mathrm{k} 3=$ number of nodal stem segments per number of in vitro-grown plants), $\mathrm{k} 4$ ( $\mathrm{k} 4=$ number of shoots per number of cultured buds) and $\mathrm{k} 5$ ( $\mathrm{k} 5=$ number of rooted plantlets per number of cultured shoots) were calculated (Fig. 2).

\section{Results}

Establishment of primary cultures and recovery of in vitro plants of 'Pineapple' sweet orange

The sequence of primary cultures is represented in Fig. 1. Shoot development from cultured nodal stem segments began 
after 4 to 6 days in culture, as reported earlier (Duran-Vila et al., 1989; Greño et al., 1988). Four months later, 20 explants had produced 60 shoots $>1 \mathrm{~cm}$ long. The shoots were transferred to rooting medium and after 21 days to elongation medium. After 1 month, 25 shoots developed roots and root primordia, and 4 months later, the rooted plantlets showed elongated roots and shoots. A sample of 10 plants was transplanted to soil and has been growing satisfactorily for 3 years. No phenotypic abnormalities have been observed. The development of primary cultures (Fig. 2) was monitored by calculating the composite multiplication factor $\mathrm{K}=\mathrm{k} 1 \times \mathrm{k} 2$. The values are summarized in Table 1.

\section{Cycle of secondary cultures of 'Pineapple' sweet orange}

A) Growth of secondary explants. The cycle of secondary cultures involved several steps: excision and subculture of nodal stem segments from in vitro-grown plants, production of shoots, rooting of shoots, and production of whole plantlets (Fig. 1). Three 4-month-old in vitro-grown plants from primary explants were divided into 20 nodal stem segments. These secondary explants were subculture, and 4 months later they produced 25 shoots $>1 \mathrm{~cm}$ long (Fig. 3). These shoots were maintained in rooting medium for 21 days, and then transferred to elongation medium. After 1 month, seven shoots had roots and root primordia. The plants recovered after 4 months were identical to the plants recovered from primary cultures. A sample of five plants was transplanted to soil and has been growing satisfactorily for 2 years. No phenotypic abnormalities have been observed. The development of secondary explants was monitored by calculating the composite multiplication factor $K^{\prime}=\mathrm{k} 3 \times$ k4 $\times$ k5 (Fig. 2). The values are summarized in Table 1 .

B) Reduction of the frequency of subcultures. Assays were performed to determine the effect of reducing the frequency of transfers on the survival and further performance of the secondary explants. Since the cycle of secondary cultures involved several steps (Fig. 1), the effect of delaying each step on the overall performance of the cultures was assayed separately.

In one assay, in vitro-grown plants obtained from primary explants were maintained for $4,6,8,10$, or 12 months on elongation medium before excising the nodal stem segments to be cultured as secondary explants. (Note that in the original assay the plants were kept in the elongation medium for 4 months.) The performance of these secondary explants was monitored by recording the number of cultures obtained in each stage and calculating the multiplication factors (Table 2).

In another assay, in vitro-grown plants obtained from primary explants were maintained for 4 months on elongation medium,

Table 1. Growth of primary and secondary cultures of sweet orange.

\begin{tabular}{clcr}
\hline \hline $\begin{array}{l}\text { Type of } \\
\text { culture }\end{array}$ & \multicolumn{1}{c}{ Stage } & \multicolumn{2}{c}{ Multiplication factors } \\
Primary & Production of shoots & $\mathrm{k} 1$ & 3.00 \\
& Production of plants & $\mathrm{k} 2$ & 0.42 \\
& Primary cultures & $\mathrm{K}=\mathrm{k} 1 \times \mathrm{k} 2$ & 1.26 \\
Secondary & Nodal stem segments & $\mathrm{k} 3$ & 6.67 \\
& Production of shoots & $\mathrm{k} 4$ & 1.25 \\
& Production of plants & $\mathrm{k} 5$ & 0.28 \\
& Secondary cultures & $\mathrm{K}^{\prime}=\mathrm{k} 3 \times \mathrm{k} 4 \times \mathrm{k} 5$ & 2.33 \\
\hline
\end{tabular}

${ }_{\mathrm{z}} \mathrm{k} 1=$ no. shoots/no. cultured buds; $\mathrm{k} 2=$ no. rooted plantlets/no. cultured shoots; $\mathrm{k} 3=$ no. nodal stem segments/no. in vitro plants; $\mathrm{k} 4$ $=$ no. shoots/no. cultured buds; $\mathrm{k} 5=$ no. rooted plantlets/no. cultured shoots.

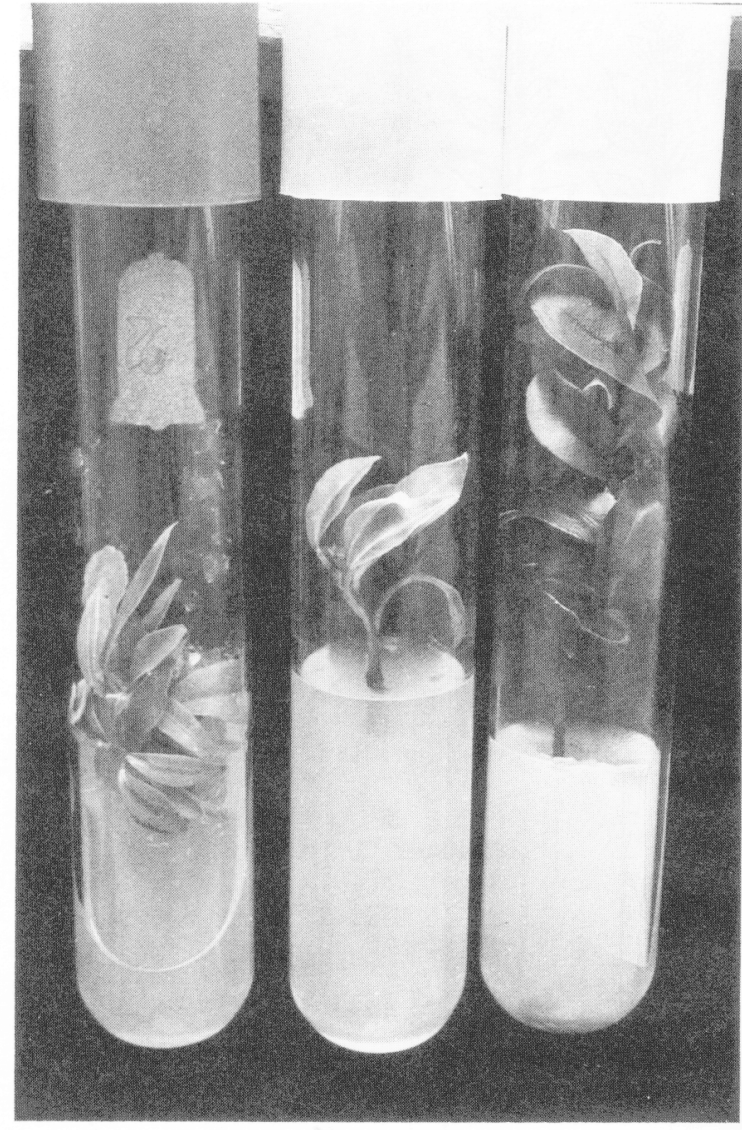

Fig. 3. Growth of primary cultures. Nodal stem segments produced shoots after 30 days in culture (left); excised shoots were transferred to rooting medium (center); and produced in vitro plants (right).

but the nodal stem segments obtained from these plants were maintained for 4,8 , or 12 months in culture before excising the shoots. (Note that in the original assay the explants were maintained on the medium for 4 months.) Recording the number of plants obtained and estimating the multiplication factors served to monitor the performance of the culture (Table 3 ).

\section{Establishment of primary cultures and cycle of subcultures of adult 'Pineapple' sweet orange}

To determine if the in vitro system defined above and the use of juvenile tissues ( 1 to 2 years old) could be used to maintain adult tissues, 20 nodal stem segments from adult 'Pineapple' sweet orange were cultured in vitro. They produced an average of 5.5 shoots per explant. The shoots were excised from the explant and transferred to rooting and elongation media, but no rooted plantlets were obtained. All attempts to recover rooted plants by modifying the composition of the rooting medium failed. Therefore, the cycle of subcultures could not be initiated.

\section{Establishment of primary cultures and cycle of subcultures of other species and cultivars}

Assays were designed to determine if the system defined using 'Pineapple' sweet orange seedlings could be used to maintain other species and cultivars. Therefore, it was necessary to determine the culture medium for each species and cultivar, to establish primary cultures, and to evaluate whether it was possible to complete a full cycle of subcultures.

A) Culture media. The medium chosen to culture explants of 


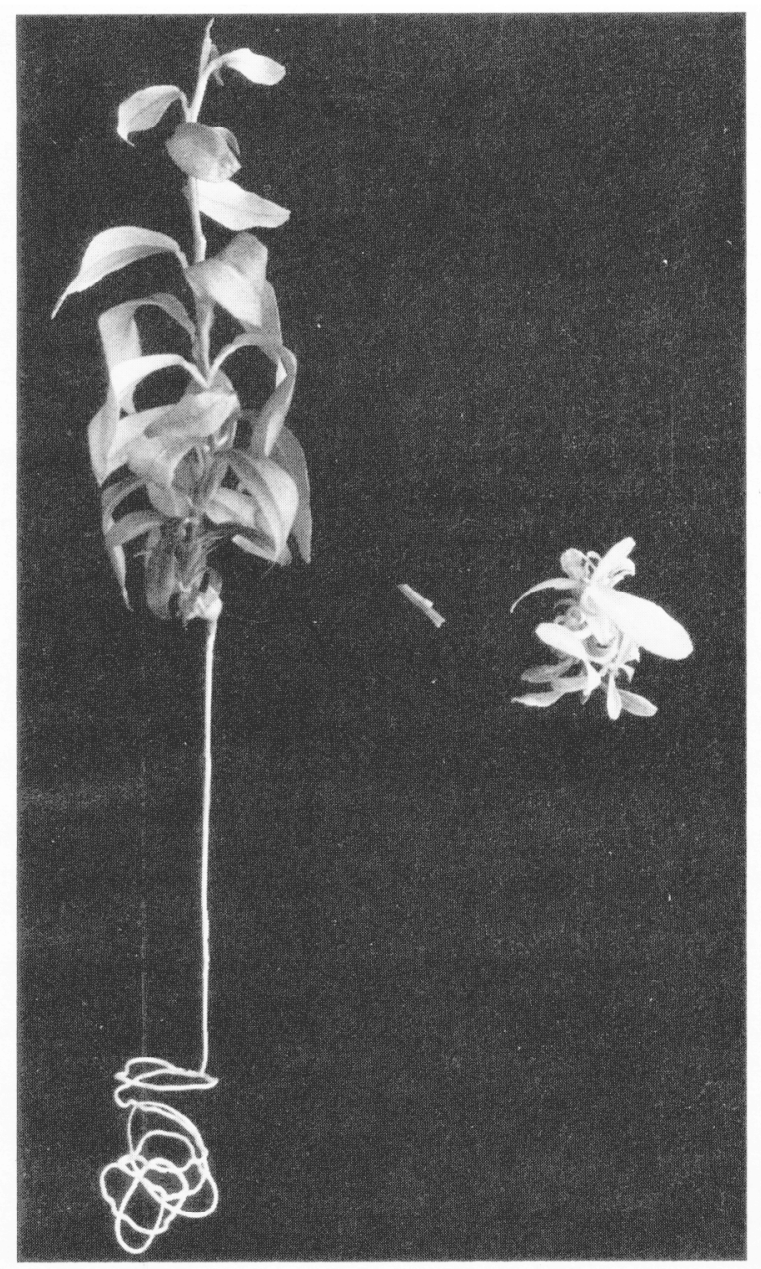

Fig. 4. Cycle of secondary cultures: In vitro plants (left) were divided into secondary nodal stem segments (center) that 30 days after subCulturing produced secondary shoots (right).

lime seedlings was the same as that used by Greño et al. (1988). To define the concentrations of BA and NAA for culturing nodal stem segments and for recovering in vitro plantlets of 'Eureka' lemon, 'Cleopatra' mandarin, 'Madame Vinous' sweet orange, trifoliate orange, and 'Duncan' grapefruit, primary explants of these species were first cultured on media containing various concentrations of BA. As reported for other species (Duran-Vila et al., 1989), the number and size of shoots developed per bud depend on the species and the BA concentration (Table 4). Significant differences were found among the BA concentrations tested by analysis of variance. Therefore, a concentration adequate for our purposes was chosen. Given that we were not interested in comparing the levels of concentrations or finding out which function better represents the relationship between the measured variables (number of shoots per explant and shoot length) and the concentration, no mean comparisons were carried out, but rather a subjective decision was made. Since small shoots rooted very poorly (Duran-Vila et al., 1989), the size and number of shoots were taken into consideration to choose the BA concentration for each species.

Excised shoots 1 to $1.5 \mathrm{~cm}$ high were transferred to rooting media containing various concentrations of NAA. After roots and root primordia were observed, the shoots were transferred to elongation medium to enhance the growth of rooted plantlets (Table 5). The concentrations of NAA chosen and the periods that the shoots from primary and secondary explants were kept in rooting and elongation media in subsequent experiments are summarized in Table 6.

B) Establishment of primary cultures and recovery of in vitro plants. Nodal stem segments were cultured under the conditions described in Table 6 and they produced shoots in the six species. The shoots were excised from the primary explants and transferred to rooting and elongation media. Plantlets with elongated shoots and roots were recovered from 'Mexican' lime, 'Eureka' lemon, 'Madame Vinous' sweet orange, trifoliate orange, and 'Duncan' grapefruit. However, none of the shoots obtained from primary explants of 'Cleopatra' mandarin rooted (Table 5). The development of primary cultures of these species was monitored by calculating the multiplication factors (Table 7). Note that k2 $=0$ and therefore $\mathrm{K}=0$ for 'Cleopatra' mandarin; whereas for the other five species $\mathrm{k} 1>1, \mathrm{k} 2>0$, and the composite factor for primary cultures $\mathrm{K}>1$.

C) Cycle of secondary cultures. Secondary explants from in vitro-grown plants were excised and transferred to fresh medium following the conditions described in Table 6 . Completion of the cycle was achieved with 'Mexican' lime, 'Eureka' lemon, 'Madame Vinous' sweet orange, and trifoliate orange; however, none of the secondary stems of 'Duncan' grapefruit produced shoots. The development of the secondary explants was monitored by calculating the multiplication factors (Fig. 2, Table 7). Note that $\mathrm{k} 4=0$ and therefore $\mathrm{K}$ ' $=0$ for 'Duncan' grapefruit; whereas for the other four species, $\mathrm{k} 3>1, \mathrm{k} 4>1, \mathrm{k} 5>0$, and the composite factor for secondary cultures is $\mathrm{K}^{\prime}>1$.

\section{Discussion}

Micropropagation protocols, including the periodical subculture of proliferating structures, have been proposed for the conservation of various vegetatively propagated crops (Styer and Chin, 1983; Withers, 1980). Attempts to maintain sweet orange by proliferating cultures of adventitious shoots or by subdividing axillary buds indicated that the cultures failed to grow after the second or third transfer (Marin, 1988). Therefore, a method

Table 2. Effect of maintaining in vitro plants for extended periods on the growth of secondary explants.

\begin{tabular}{|c|c|c|c|c|c|c|c|c|}
\hline $\begin{array}{l}\text { Age of plants } \\
\text { (months) }\end{array}$ & $\begin{array}{c}\text { Shoots } \\
\text { used (no.) }\end{array}$ & $\begin{array}{l}\text { Production } \\
\text { of nodal stem } \\
\text { segments }\end{array}$ & $\mathrm{k}^{\mathrm{z}}$ & $\begin{array}{c}\text { Production } \\
\text { of } \\
\text { shoots }\end{array}$ & $\mathrm{k} 4^{\mathbf{z}}$ & $\begin{array}{c}\text { Production } \\
\text { of } \\
\text { plants }\end{array}$ & $\mathbf{k} 5^{\mathbf{z}}$ & $(\mathrm{k} 3 \times \mathrm{k} 4 \times \mathrm{k} 5)$ \\
\hline 4 & 8 & 60 & 7.50 & 65 & 1.08 & 25 & 0.38 & 3.07 \\
\hline 6 & 8 & 60 & 7.50 & 52 & 0.86 & 24 & 0.46 & 2.90 \\
\hline 8 & 6 & 60 & 10.00 & 60 & 1.00 & 28 & 0.46 & 4.60 \\
\hline 10 & 2 & 20 & 10.00 & 20 & 1.00 & 6 & 0.30 & 3.00 \\
\hline 12 & 4 & 20 & 5.00 & 20 & 1.00 & 13 & 0.65 & 3.25 \\
\hline
\end{tabular}

${ }^{\mathrm{z}} \mathrm{k} 3=$ no. nodal stem segments/no. in vitro plants; $\mathrm{k} 4=$ no. shoots/no. cultured buds; $\mathrm{k} 5=$ no. rooted plantlets/no. cultured shoots. 
Table 3. Effect of maintaining nodal segments for extended periods on the growth of secondary cultures.

\begin{tabular}{cccc}
\hline \hline $\begin{array}{c}\text { Age of segments } \\
\text { (months) }\end{array}$ & $\begin{array}{c}\text { Nodal segments used } \\
\text { (no.) }\end{array}$ & $\begin{array}{c}\text { Plants } \\
\text { produced (no.) }\end{array}$ & $\mathrm{k5}^{\mathbf{z}}$ \\
\hline 4 & 60 & 25 & 0.41 \\
8 & 25 & 12 & 0.48 \\
12 & 14 & 8 & 0.57 \\
\hline
\end{tabular}

${ }^{2} \mathrm{k} 5=$ No. rooted plantlets/no. cultured shoots

based on the periodic recovery of rooted plantlets in each subculture cycle was explored as an alternative approach.

The establishment of primary cultures to recover in vitro plants and the maintenance of successive cycles of secondary cultures, as described here, would permit the long-term maintenance of juvenile 'Pineapple' and 'Madame Vinous' sweet orange, 'Mexican' lime, 'Eureka' lemon, and trifoliate orange. The values for $\mathrm{K}$ and $\mathrm{K}$ ' must be $\geq 1$ to accomplish the conservation of plant materials for a given species or variety. Values of $K>1$ imply that primary cultures were successfully established, an adequate number of plantlets was recovered, and the cycle of secondary cultures could be initiated. Since $\mathrm{K}=\mathrm{k} 1 \times \mathrm{k} 2$, low values of $\mathrm{k} 2$ (note that $0<\mathrm{k} 2<1$ ) may restrict the $\mathrm{K}$ values within an adequate range. The $\mathrm{k} 2$ reflects the rooting efficiency of the species and seems to be the limiting factor. Failure of shoots to root $(\mathrm{k} 2=0)$ prevented the application of the proposed scheme for genetic conservation to 'Cleopatra' mandarin. In the other species, even when low $\mathrm{k} 2$ values were obtained (note, $\mathrm{k} 2=0.42$ for 'Pineapple' sweet orange in Table 1 and $\mathrm{k} 2=0.55$ for 'Madame Vinous' sweet orange in Table 7), a value $K>1$ was obtained because sufficiently large $k 1$ values were consistently obtained.

Values of $\mathrm{K}^{\prime}>1$ imply that the cycle of secondary cultures was successfully established, an adequate number of plantlets was recovered, and the cycle could be reinitiated. If $K^{\prime}>1$, the output at the end of the cycle is greater than the input (the number of plants recovered is greater than the number of plants used to initiate the cycle), and therefore the cycle can occur with minimum risk of losing the plant material. If $\mathrm{K}^{\prime}=1$, the cycle of secondary cultures falls in a steady-state equilibrium, and the output at the end of the cycle is identical to the input. The number of plants recovered is the same as the number of plants used to initiate the cycle, and therefore completion of the next cycle may not be feasible.

Since $\mathrm{K}^{\prime}=\mathrm{k} 3 \times \mathrm{k} 4 \times \mathrm{k} 5$, low values of $\mathrm{k} 5$ (note that $0<\mathrm{k} 5<1)$ may restrict the $\mathrm{K}$ ' values within an adequate range. As discussed for $\mathrm{k} 2, \mathrm{k} 5$ also reflects the rooting efficiency of the species and, therefore, is a limiting factor for the cycle of secondary cultures. However, as discussed for primary cultures, even when low $\mathrm{k} 5$ values were obtained (note, $\mathrm{k} 5=$ 0.28 for 'Pineapple' sweet orange in Table 1 and $\mathrm{k} 5=0.35$ for trifoliate orange in Table 7 ), a value $K^{\prime}>1$ was obtained because greater k3 values were consistently obtained. Poor flushing of cultured buds also resulted in low $\mathrm{k} 4$ values (note, $\mathrm{k} 4=0$ for 'Duncan' grapefruit and $\mathrm{k} 4=1.1$ for trifoliate orange in Table 7) and, therefore, also low K' values. Failure of buds to produce shoots $(\mathrm{k} 4=0)$ prevented application of the proposed scheme for genetic conservation to 'Duncan' grapefruit $\left(\mathrm{K}^{\prime}=0\right)$; however, the subculture cycle of trifoliate orange could be completed $\left(K^{\prime}=1.27\right)$ in spite of low $k 4$ and $\mathrm{k} 5$ values.

The limitations of tissue culture systems for conservation of genetic resources include the number, frequency, and complexity of routinely performed operations (Tisserat et al., 1979). The subculture cycle described would last 8 months and would include the performance of several operations (culture of nodal segments, rooting of shoots, and elongation of rooted plantlets). However, it has been shown that the frequency of subcultures can be safely reduced by maintaining plantlets and nodal stem segments for up to 12 months on the same medium before subculture to fresh media. As shown in Tables 2 and 3, the cycle would then last 2 years. During the 1st year a single operation (culture of nodal stem segments) should be performed, and the 2nd year should include two closely related operations (excision of buds and transfer to rooting media followed by a transfer to elongation medium). The rooted plantlet can then remain for 12 months in the same medium before reinitiating the cycle. Estimates of $\mathrm{K}^{\prime}$ for a 2-year cycle would be as follows: $\mathrm{K}^{\prime}=\mathrm{k} 3$ $\times \mathrm{k} 4 \times \mathrm{k} 5=5.0 \times 1.0 \times 0.57=2.85$ (note $\mathrm{k} 3=5.0$ and $\mathrm{k} 4=1.0$ in Table 2 and $\mathrm{k} 5=0.57$ in Table 3 ), being actually greater than $\mathrm{K}^{\prime}=2.33$ calculated for an 8-month cycle (Table $1)$.

The establishment of primary cultures followed by successive 2 -year cycles of secondary cultures would allow the conservation of juvenile tissue cultures of 'Pineapple' sweet orange using relatively small samples. The results obtained with juvenile tissues of other species and varieties indicate that the same system may be used for 'Mexican' lime, 'Eureka' lemon, 'Madame Vinous' sweet orange, and trifoliate orange. The optimal BA and NAA concentration in the culture medium (Tables 4 and 5)

Table 4. Mean number of shoots per explant and shoot length on bud cultures of five citrus species cultured on media containing BA.

\begin{tabular}{|c|c|c|c|c|c|c|c|c|c|c|}
\hline \multirow[b]{2}{*}{$\begin{array}{l}\text { BA } \\
\left(\mathrm{mg} \cdot \text { liter }^{-1}\right)\end{array}$} & \multicolumn{2}{|c|}{$\begin{array}{l}\text { Eureka } \\
\text { lemon }\end{array}$} & \multicolumn{2}{|c|}{$\begin{array}{l}\text { Cleopatra } \\
\text { mandarin }\end{array}$} & \multicolumn{2}{|c|}{$\begin{array}{c}\text { Madame } \\
\text { Vinous } \\
\text { sweet orange }\end{array}$} & \multicolumn{2}{|c|}{$\begin{array}{c}\text { Trifoliate } \\
\text { orange }\end{array}$} & \multicolumn{2}{|c|}{$\begin{array}{l}\text { Duncan } \\
\text { grapefruit }\end{array}$} \\
\hline & $\begin{array}{l}\text { Shoots/ } \\
\text { explant } \\
\text { (no.) }\end{array}$ & $\begin{array}{c}\text { Shoot } \\
\text { length } \\
(\mathrm{mm})\end{array}$ & $\begin{array}{l}\text { Shoots/ } \\
\text { explant } \\
\text { (no.) }\end{array}$ & $\begin{array}{c}\text { Shoot } \\
\text { length } \\
(\mathrm{mm})\end{array}$ & $\begin{array}{c}\text { Shoots/ } \\
\text { explant } \\
\text { (no.) }\end{array}$ & $\begin{array}{l}\text { Shoot } \\
\text { length } \\
(\mathrm{mm})\end{array}$ & $\begin{array}{l}\text { Shoots/ } \\
\text { explant } \\
\text { (no.) }\end{array}$ & $\begin{array}{l}\text { Shoot } \\
\text { length } \\
(\mathrm{mm})\end{array}$ & $\begin{array}{l}\text { Shoots/ } \\
\text { explant } \\
\text { (no.) }\end{array}$ & $\begin{array}{l}\text { Shoot } \\
\text { length } \\
(\mathrm{mm})\end{array}$ \\
\hline 0 & 1.2 & 20.4 & 1.2 & 12.4 & 1.4 & 21.5 & 1.0 & 4.0 & 1.6 & 15.1 \\
\hline 0.3 & 2.1 & 16.9 & 1.5 & 9.5 & 1.5 & 17.3 & 1.7 & 5.6 & 1.5 & 15.9 \\
\hline 1 & 2.3 & 13.4 & 2.2 & 8.7 & 3.0 & 12.0 & 2.6 & 6.6 & 2.0 & 14.9 \\
\hline 3 & 1.4 & 12.6 & 2.3 & 3.8 & 2.8 & 8.5 & 3.8 & 3.7 & 2.0 & 8.7 \\
\hline 10 & 1.7 & 1.6 & 0.0 & 0.0 & 1.9 & 4.2 & 4.7 & 3.4 & 1.3 & 5.7 \\
\hline
\end{tabular}

${ }^{7}$ Data were recorded 2 months after cultures had been initiated. In all assays 20 explants per treatment were used. Values on columns were compared by analysis of variance $(P<$ $0.01)$ and were significantly different. 
Table 5. Recovery of rooted plantlets of five citrus species on media containing NAA. ${ }^{2}$

\begin{tabular}{|c|c|c|c|c|c|c|c|c|c|c|}
\hline \multirow[b]{3}{*}{$\begin{array}{l}\text { NAA } \\
\left(\mathrm{mg} \cdot \text { liter }^{-1}\right)\end{array}$} & \multirow{2}{*}{\multicolumn{2}{|c|}{$\begin{array}{c}\text { Eureka } \\
\text { lemon }\end{array}$}} & \multirow{2}{*}{\multicolumn{2}{|c|}{$\begin{array}{c}\begin{array}{c}\text { Cleopatra } \\
\text { mandarin }\end{array} \\
\text { Frequency }(\%)\end{array}$}} & \multirow{2}{*}{\multicolumn{2}{|c|}{$\begin{array}{c}\text { Madame Vinous } \\
\text { sweet orange }\end{array}$}} & \multirow{2}{*}{\multicolumn{2}{|c|}{$\begin{array}{c}\begin{array}{c}\text { Trifoliate } \\
\text { orange }\end{array} \\
\text { Frequency }(\%) \\
\end{array}$}} & \multirow{2}{*}{\multicolumn{2}{|c|}{$\begin{array}{c}\begin{array}{c}\text { Duncan } \\
\text { grapefruit }\end{array} \\
\text { Frequency (\%) }\end{array}$}} \\
\hline & & & & & & & & & & \\
\hline & $\begin{array}{l}\text { Rooted } \\
\text { cultures }\end{array}$ & $\begin{array}{c}\text { Elongated } \\
\text { plants }\end{array}$ & $\begin{array}{l}\text { Rooted } \\
\text { cultures }\end{array}$ & $\begin{array}{c}\text { Elongated } \\
\text { plants }\end{array}$ & $\begin{array}{l}\text { Rooted } \\
\text { cultures }\end{array}$ & $\begin{array}{c}\text { Elongated } \\
\text { plants }\end{array}$ & $\begin{array}{l}\text { Rooted } \\
\text { cultures }\end{array}$ & $\begin{array}{c}\text { Elongated } \\
\text { plants }\end{array}$ & $\begin{array}{c}\text { Rooted } \\
\text { cultures }\end{array}$ & $\begin{array}{c}\text { Elongated } \\
\text { plants }\end{array}$ \\
\hline 0 & 35 & 0 & 0 & 0 & 15 & 0 & 15 & 0 & 15 & 0 \\
\hline 0.3 & $100^{* *}$ & 40 & 0 & 0 & 0 & 0 & $20^{\text {NS }}$ & 0 & $25^{\mathrm{NS}}$ & 0 \\
\hline 1 & $100^{* *}$ & 45 & 0 & 0 & 55 & 10 & $30^{\mathrm{NS}}$ & 5 & $25^{\mathrm{NS}}$ & 0 \\
\hline 3 & $100^{* *}$ & 50 & 0 & 0 & 50 & 0 & $75^{* *}$ & 15 & $80^{* *}$ & 0 \\
\hline 10 & $100^{* *}$ & 40 & 0 & 0 & 55 & 10 & $75^{* *}$ & 15 & $60 * *$ & 15 \\
\hline
\end{tabular}

${ }^{2}$ Data were recorded 3 months after being transfered to elongation medium. Frequencies were compared with controls by $\chi^{2}$ test $(P<0.01)$.

Table 6. Primary and secondary cultures of six citrus species: BA and NAA concentrations in culture media and period between transfers.

\begin{tabular}{|c|c|c|c|c|c|c|c|c|c|c|}
\hline \multirow[b]{4}{*}{ Species } & \multicolumn{5}{|c|}{ Primary cultures } & \multicolumn{5}{|c|}{ Cycle of secondary cultures } \\
\hline & \multicolumn{2}{|c|}{ Nodal stem segments } & \multirow{2}{*}{\multicolumn{2}{|c|}{ Rooting }} & \multirow{3}{*}{$\begin{array}{c}\begin{array}{c}\text { Elonga- } \\
\text { tion }\end{array} \\
\text { Time } \\
\text { (months) }\end{array}$} & \multicolumn{2}{|c|}{ Nodal stem segments } & \multirow{2}{*}{\multicolumn{2}{|c|}{ Rooting }} & \multirow{3}{*}{$\begin{array}{c}\begin{array}{c}\text { Elonga- } \\
\text { tion }\end{array} \\
\text { Time } \\
\text { (months) }\end{array}$} \\
\hline & & Time in & & & & \multirow{2}{*}{$\begin{array}{c}\mathrm{BA} \\
\left(\mathrm{mg} \cdot \text { liter }^{-1}\right)\end{array}$} & \multirow{2}{*}{$\begin{array}{l}\text { Time in } \\
\text { culture } \\
\text { (months) }\end{array}$} & & & \\
\hline & $\begin{array}{c}\text { BA } \\
\left(\mathrm{mg} \cdot \text { liter }^{-1}\right)\end{array}$ & $\begin{array}{c}\text { culture } \\
\text { (months) }\end{array}$ & $\begin{array}{c}\text { NAA } \\
\left(\mathrm{mg} \cdot \text { liter }^{-1}\right)\end{array}$ & $\begin{array}{c}\text { Time } \\
\text { (days) }\end{array}$ & & & & $\begin{array}{c}\text { NAA } \\
\left(\mathrm{mg} \cdot \text { liter }^{-1}\right)\end{array}$ & $\begin{array}{c}\text { Time } \\
\text { (days) }\end{array}$ & \\
\hline $\overrightarrow{\text { Mexican lime }}$ & 0.3 & 2 & 3 & 21 & 3 & 0.3 & 2 & 3 & 21 & 3 \\
\hline Eureka lemon & 1 & 1 & 0.3 & 12 & 1 & 1 & 2 & 0.3 & 18 & 3 \\
\hline $\begin{array}{l}\text { Cleopatra mandarin } \\
\text { Madame Vinous }\end{array}$ & 1 & 2 & $\ldots z$ & -- & -- & -- & -- & $\cdots$ & --- & -- \\
\hline sweet orange & 1 & 2 & 1 & 21 & 4 & 1 & 2 & 1 & 22 & 4 \\
\hline Trifoliate orange & 1 & 2 & 3 & 30 & 5 & 1 & 2 & 3 & 52 & 4 \\
\hline Duncan grapefruit & 1 & 1 & 10 & 21 & 4 & $--y$ & & & & \\
\hline
\end{tabular}

${ }^{2}$ As shown in Table 5, shoots obtained from Cleopatra mandarin explants did not root at any NAA concentration tested.

'Secondary stem segments failed to grow.

Table 7. Multiplication factors of primary and secondary cultures of six citrus species. ${ }^{z}$

\begin{tabular}{|c|c|c|c|c|c|c|c|}
\hline \multirow[b]{2}{*}{ Species } & \multicolumn{3}{|c|}{$\begin{array}{l}\text { namury } \\
\text { cultures }\end{array}$} & \multicolumn{4}{|c|}{ Secondary cultures } \\
\hline & $\mathrm{k} 1$ & $\mathrm{k} 2$ & $\mathrm{~K}$ & $\mathrm{k} 3$ & k4 & $\mathrm{k} 5$ & $\mathbf{K}^{\prime}$ \\
\hline Mexican lime & 2.50 & 0.85 & 2.12 & 6.15 & 3.80 & 0.80 & 18.7 \\
\hline Eureka lemon & 2.30 & 1.00 & 2.30 & 5.00 & 1.50 & 0.40 & 3.00 \\
\hline $\begin{array}{l}\text { Cleopatra mandarin } \\
\text { Madame Vinous }\end{array}$ & 2.20 & $0^{y}$ & 0 & $-\cdots$ & --- & --- & --- \\
\hline sweet orange & 3.00 & 0.55 & 1.65 & 4.00 & 2.20 & 0.75 & 6.60 \\
\hline Trifoliate orange & 2.60 & 0.75 & 1.95 & 3.30 & 1.10 & 0.35 & 1.27 \\
\hline Duncan grapefruit & 2.00 & 0.60 & 1.20 & 5.70 & $0^{\mathrm{x}}$ & --- & 0 \\
\hline
\end{tabular}

${ }_{\mathrm{z}} \mathrm{k} 1=$ no. shoots/no. cultured buds; $\mathrm{k} 2=$ no. rooted plantlets/no. cultured shoots; $\mathrm{K}=\mathrm{k} 1 \times \mathrm{k} 2 ; \mathrm{k} 3=$ no. nodal stem segments/no. in vitro plants; $\mathrm{k} 4=$ no. shoots/no. cultured buds; $\mathrm{k} 5=$ no. rooted plantlets/no. cultured shoots; $\mathrm{K}^{\prime}=\mathrm{k} 3 \times \mathrm{k} 4 \times \mathrm{k} 5$.

${ }^{y}$ The shoots obtained from Cleopatra mandarin explants did not root. ${ }^{\mathrm{x}}$ Secondary nodal stem segments of 'Duncan' grapefruit did not produce shoots.

seems to vary considerably among species; therefore, preliminary assays would be advisable before attempting conservation of new species. However, little variation was observed among seedlings of varieties within the same species.

In summary, the application of protocol described allows the conservation and monitoring of citrus tissue cultures. The manipulation (one or two operations per year) of relatively small samples is the only requirement, whereas the systems established for other crops require frequent operations (Henshaw et al., 1980; Hensky et al., 1983; Rota et al., 1979), unless the cultures are maintained under minimal growth conditions (Galzy,
1985; Lundergan and Janick, 1979; Roca et al., 1979). Since whole plants are periodically recovered, the morphogenic potential of the cultures is guaranteed and true-to-type tests may be performed. The system can be readily applied to many citrus species and relatives while awaiting development of better techniques.

\section{Literature Cited}

Bajaj, Y.P.S. 1979. Technology and prospects of cryopreservation of germplasm. Euphytica 28:267-285.

Bajaj, Y.P.S. (ed.). 1986. Biotechnology in agriculture and forestry. vol. 1. Springer-Verlag, Berlin.

Barlass, M. and K.G.M. Skene. 1982. In vitro plantlet formation from citrus species and hybrids. Scientia Hort. 17:333-341.

Boxus, P. 1974. The production of strawberry plants by in vitro micropropagation. J. Hort. Sci. 49:209-210.

Chaturvedi, H.C. and G. Mitra. 1974. Clonal propagation of Citrus from somatic callus cultures. HortScience 9:118-120.

Duran-Vila, N., V. Ortega, and L. Navarro. 1989. Morphogenesis and tissue cultures of three citrus species. Plant Cell Tissue Organ Culture 16: 123-133.

Galzy, R. 1985. Les possibilités de conservation in vitro d'une collection de clones de vignes. Bul. de l'OIV. (650-651):377-390.

Greño, V., L. Navarro, and N. Duran-Vila. 1988. Influence of virus and virus-like agents on the development of citrus buds cultured in vitro. Plant Cell Tissue Organ Culture 15:113-124.

Henshaw, G.G., J.F. O'Hara and R.J. Westcott. 1980. Tissue culture methods for the storage and utilization of potato germplasm, p. 7176. In: D.S. Ingram and J.P. Helgeson (eds.). Tissue culture methods for plant pathologists. Blackwell Scientific, Oxford.

Hensky, L.E., K. Enyingi, and I. Szabo. 1983. Tissue culture technology for long-term storage and propagation of potato (Solarium 
tuberosum L.) germplasm, p. 9-18. In: S.K. Sen and K.L. Giles (eds.). Plant cell culture in crop improvement. Plenum, New York.

Honjo, H. and Y. Nakagawa. 1978. Suitable temperature and seed moisture content for maintaining the germinability of citrus seed for long term storage, p. 31-35. In: T. Akihama and K. Nakajima (eds.). Long term preservation of favorable germplasm in arboreal crops. Kokusai Print Service, Tokyo.

IBPGR. 1982. Genetic resources of citrus. AGP:IBPGR/82/7. Rome.

Kartha, K.K. 1981. Meristem culture and cryopreservation. Methods and applications, p. 181-211. In: A. Thorpe (ed.). Plant tissue culture methods in agriculture. Academic, New York.

Kartha, K.K., L.A. Mroginski, K. Pahl, and N.L. Leung. 1981. Germplasm preservation of coffee (Coffea Arabica L.) by in vitro culture of shoot apical meristems. Plant Sci. Lett. 22:301-307.

King, M.W., U. Soetisna, and E.H. Roberts. 1981. The dry storage of citrus seeds. Ann. Bot. 48:865-872.

Lundergan, C. and J. Janick. 1979. Low temperature storage of in vitro apple shoots. HortScience 14:514.

Marin, M.L. 1988. Conservación de germoplasma de citricos por cultivo in vitro. Ph.D. Diss., Universidad de Oviedo, Spain.

Marin, M.L. and N. Duran-Vila. 1988. Survival of somatic embryos and recovery of plants of sweet orange (Citrus sinensis (L.) Osb.) after immersion in liquid nitrogen. Plant Cell Tissue Organ Culture 14:51-57.

Mumford, P.M. and B.W.W. Grout. 1979. Desiccation and low tem- perature $\left(-196^{\circ}\right)$ tolerance of Citrus limon seed. Seed Sci. Technol. 7:407-410.

Murashige, T. and F. Skoog. 1962. A revised medium for rapid growth and bioassays with tobacco tissue culture. Physiol. Plant. 15:473497.

Rota, W.M., J.E. Bryan, and M.R. Roca. 1979. Tissue culture for the international transfer of potato genetic resources. Amer. Potato J. $56: 1-10$.

Rota, W.M., J. Rodriguez, J. Beltran, J. Roa, and G. Mafla. 1982. Tissue culture for the conservation and international exchange of germplasm. Proc. Vth Intl. Congr. Plant Tissue and Cell Culture (Tokyo). p. 771-772.

Sakai, A. 1986. Cryoconservation of germplasm of woody plants, p. 113-129. In: Y.P.S. Bajaj (ed.). Biotechnology in agriculture and forestry. vol. 1. Springer-Verlag, Berlin.

Styer, D.J. and C.K. Chin. 1983. Meristem and shoot-tip culture for propagation, pathogen elimination and germplasm preservation. Hort. Rev. 5:221-277.

Tisserat, B., E.B. Esan, and T. Murashige. 1979. Somatic embryogenesis in angiosperms. Hort. Rev. 1:1-78.

Withers, L. 1980. Tissue culture storage for genetic conservation. AGP: IBPGR/80/8. Rome.

Withers, L. 1985. Cryopreservation and storage of germplasm, p. 169191. In: R.A. Dixon (ed.). Plant cell culture, a practical approach. IRL Press, Oxford. 